UDC 614/5: 644.36

DOI: 10.21668/health.risk/2017.2.02.eng

\title{
HEALTH RISKS OCCURRING WHEN COLOR IS PERCEPTED UNDER LED LIGHTING
}

\author{
V.A. Kaptsov ${ }^{1}$, V.N. Deinego ${ }^{2}$ \\ ${ }^{1}$ All-Russian Research Institute of Railway Hygiene, 1 Pakgauznoe Shosse Str., Bldg. 1, Moscow, 125438, Russian Faderation \\ ${ }^{2}$ New energy technologies, 100 Novaya Str., Skolkovo, Moscow region, 143025, Russian Federation
}

The article deals with problems of color perception under LED lighting. We revealed that inadequate perception of a signal color by a driver led to greater risks of transport accidents. We reviewed both Jung-Helmholtz three-color hypothesis and a modern one based on fiber-optical approach to functioning of "Mueller cells and cones" system. We made an attempt to explain a number of effects related to visibility curves and time delays when defining color of light signals. Our research on assessing influence exerted by LED lighting on functional state and working capacity of railway workers during which we applied occupational selection techniques revealed negative changes. We proved there was a decrease in functional resistance to color sense between red and green signals as well as longer response time for complicated sight-motor reaction and significant decrease in readiness to emergency actions (resistance to monotony) in examined individuals. The article also contains data on time peculiarities which are characteristic for defining signals color in relation to red signal $(650 \mathrm{~nm})$. We showed that when red color LEDs with wave length much shorter than $650 \mathrm{~nm}$ were used in signaling devices it caused risks of inadequate color detection, longer reaction to inhibiting signals, and greater possibility of transport accidents and negative events in everyday life. These peculiarities should be taken into account when designing traffic lights and other signaling devices which provide transport safety. We also proved that signaling traffic lights for transport systems should be designed allowing for physiology of color perception by a human visual analyzer; application of LEDs with wave length shorter than $650 \mathrm{~nm}$ should be absolutely excluded.

Key words: LED lighting, color, traffic lights, LEDs, Mueller cells, cones, red light, fiber-optical eye system.

The nature speaks to the man using the language of environmental colors. At first sight, a color may seem to be easy to understand. But in reality color signals contain certain information and exert significant influence on our life changing our mood, emotions, and the way we feel ourselves. Color sometimes manages life itself, for example, when inadequate color determination in perception of warning and inhibit transport signals occurs. Color is a language of our life. We are not always able to translate it but we feel it inside and our instincts make us follow its laws. Our reactions to color are programmed in our genes; our love for certain colors changes depending on the world and our self-sense.

A sight object is visible. Aristotle noted in his works that "...what we see is color. Color belongs to something which is visible in itself; in itself not meaning that it is its essence to be visible, but meaning that it in its nature has the reasons which make it visible. Any color is something that moves really transparent things and it is its true nature. That is why we cannot see light without color, and any color of each object is visible under light". Nowadays a paradigm based on Jung-Helmholtz three-color hypothesis is widely spread among ophthalmologists and light technicians; they use it to describe a color sense model [6]. As per this hypothesis, to get the best determination, color image is to be focused into a hole where the cones density is the greatest. To achieve this, the eye pupil is to react adequately to lighting spectrum which a color object is located in. Under LED lighting a pupil diameter is greater

(C) Kaptsov V.A., Deinego V.N., 2017

Valeriy A. Kaptsov - Corresponding Member of Russian Academy of Sciences, Doctor of Medical Sciences, prof., Head of the Occupational Health Department (e-mail: kapcovva39@ mail.ru; tel.: + 7 (499) 153-36-28).

Vitaly N. Deinego - Light technique project manager (e-mail: aet@aetechnologies.ru; tel.: + 7 (495) 280-76-07). 
than under sunlight and it doesn't provide $100 \%$ determination of an object color $[1-3,5,14$ $16]$.

Allowing for the influence exerted by LED light spectrum on the eye functions and locomotive drivers health, experts from the AllRussian Research Institute of Railway Hygiene of Rospotrebnadzor accomplished the research on impacts exerted by diffused LED light and luminous light from regular lamps on psychophysiological state of a man. The research was initiated by "Russian Railways" PLC. Working places of an experimental plant and all the lamps were certified by the leading technical experts from All-Russian Research Institute of Railway Hygiene and "Russian Railways" PLC.

The accomplished research on assessing influence exerted by LED lighting on functional state and working capacity of railway workers with application of certified occupational selection techniques revealed negative changes. Thus, functional resistance to color sense of red and green signals reduced, response time of a complicated sight-motor reaction became longer, and readiness to emergency actions (resistance to monotony) in all the examined people decrease significantly.

Experts from Yuzhno-Uralskiy State University also noted that volunteers aged 20-25 had poorer light and color sense at the end of the performed research on assessing influence exerted by LED lighting on the human visual analyzer. This peculiarity is important for a number of occupations, notably, surgeons, car drivers, bikers, traffic controllers and locomotive drivers, atomic power station operators, as well as operators at specialized objects of the Defense Ministry. Inadequate color determination increases emergency risks; such emergencies can have various gravity, for a man and population as a whole (when incidents at atomic power stations occur). Therefore, an issue of adequate color sense when receiving light signals is truly vital.

If we take passers-by and city transport drivers, we can say that it is quite enough for them to correctly react to three color signals: red, yellow, and green. Railway workers are to perceive correctly and to react adequately to the whole color spectrum. Thus, "Guidelines on signaling system functioning at railroads in the Russian Federation" fixes the following signals:

- one green signal - «Movement with set speed is allowed»;

- one yellow flashing signal - «Movement with set speed is allowed; the next traffic light is open and it is required to pass it at slower speed»;

- one yellow light - «movement is allowed with readiness to stop; the next traffic light is closed»;

- two yellow lights, the upper one is flashing, - «It is allowed to pass the traffic light with slower speed; the train goes through the switch; the next traffic light is open»;

- two yellow lights - «It is allowed to pass the traffic light with and readiness to stop at the next traffic light; the train goes through the switch»;

- one moon-white flashing light allows a train to go through a traffic light with red color signal (or without any signal) and move to the next traffic light (or up to the last stake when going into a way without the output signal) at a speed not faster than $20 \mathrm{~km} / \mathrm{hour}$;

- one red light $-\ll$ Stop! It is prohibited to pass the signal».

A lot of works are dedicated to color signals perception $[4,8,9]$. Most of such works deal with red color signals with wave length considerably shorter than 650 nanometers. Figure 1 shows coordinates for red color coloration and wave length from 610 to 700 nanometers.

M.J. Flannagan, D.F. Blower and J.M. Devonshire in their work [9] determine red light with coloration coordinates - 0,$66 ; 0,34$, it corresponds to a wave shorter than 610 nanometers (Tables 1, 2).

Ju. Luoma et al. [8] determine red light with coloration coordinates $-0,715 ; 0,283$, it corresponds to a wave shorter than 636 nanometers. Figure 2 shows light sources spectra which were used in the research. Table 3 details photometric values for LED lamps. 


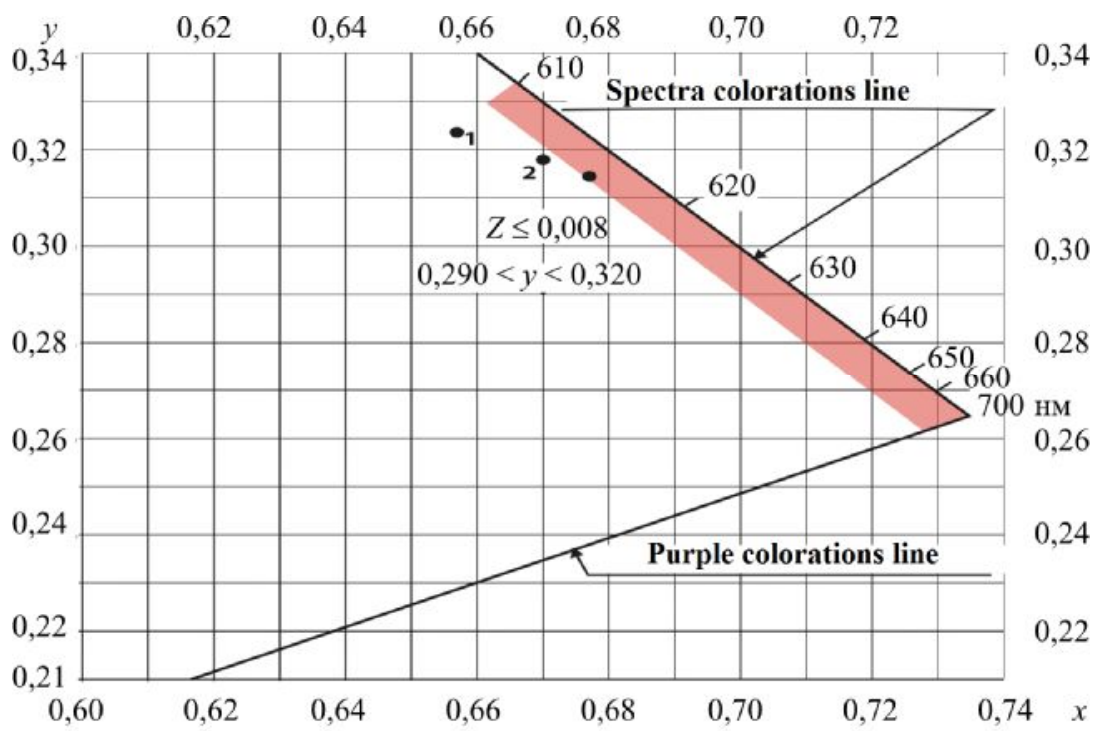

Figure 1. Coloration coordinates for red light

Table 1

Average lamp brightness at corresponding coloration coordinates

\begin{tabular}{|l|c|c|c|c|}
\hline \multirow{2}{*}{ Lamp } & \multicolumn{2}{c|}{ Brightness $(c d)$} & \multicolumn{2}{c|}{ Coloration coordinates } \\
\cline { 2 - 5 } & Without filter & With filter & $X$ & $Y$ \\
\hline Yellow turning signal & 130 & 30 & 0,57 & 0,43 \\
\hline Red turning signal & 130 & 79 & 0,66 & 0,34 \\
\hline Red stop-signal (at an engine level) & \multicolumn{2}{|c|}{81} & 0,66 & 0,34 \\
\hline Red stop-signal (above an engine level) & \multicolumn{2}{|c|}{25} & 0,66 & 0,34 \\
\hline
\end{tabular}

Table 2

Percentage of prompt and correct replies as well as slow and incorrect replies depending on color of signals detailed in Table 1

\begin{tabular}{|l|c|c|}
\hline \multirow{2}{*}{\multicolumn{1}{|c|}{ Reply }} & \multicolumn{2}{c|}{ Signal color } \\
\cline { 2 - 3 } & red & yellow \\
\hline Prompt and correct & 89,8 & 95,9 \\
\hline Slow or incorrect & 10,2 & 4,1 \\
\hline
\end{tabular}

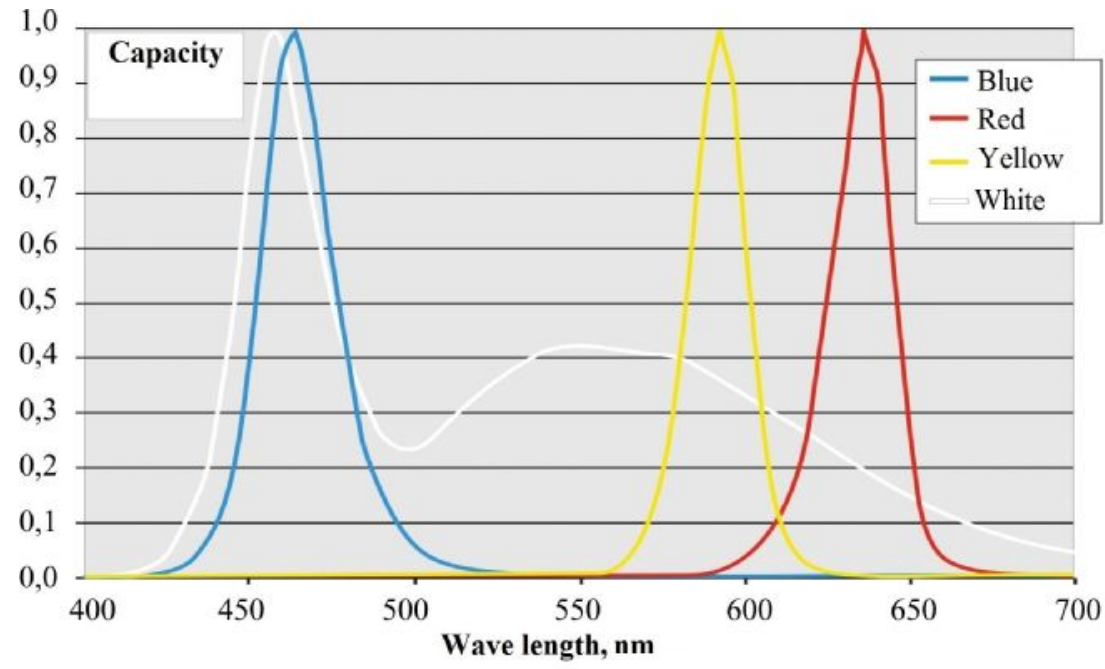

Figure 2. Spectra of blue, red, yellow, and white LEDs 
Table 3

Photometric values for LED lamps

\begin{tabular}{|c|c|c|c|c|c|}
\hline \multirow{2}{*}{ LED color } & \multirow{2}{*}{$S / P$} & \multirow{2}{*}{$\begin{array}{l}\text { Wave length } \\
\text { (nm) }\end{array}$} & \multirow{2}{*}{ Intensity } & \multicolumn{2}{|c|}{ Light intensity } \\
\hline & & & & At photooptic sight $(c d)$ & At night sight $(c d)$ \\
\hline \multirow{2}{*}{ Blue } & \multirow{2}{*}{16,4} & \multirow{2}{*}{464} & High & 1,444 & 23,617 \\
\hline & & & Low & 604 & 9,878 \\
\hline \multirow{2}{*}{ Red } & \multirow{2}{*}{0,069} & \multirow{2}{*}{636} & High & 4,260 & 295 \\
\hline & & & Low & 2,112 & 146 \\
\hline \multirow{2}{*}{ Yellow } & \multirow{2}{*}{0,246} & \multirow{2}{*}{592} & High & 2,060 & 507 \\
\hline & & & Low & 1,276 & 314 \\
\hline \multirow{2}{*}{ White } & \multirow{2}{*}{2,52} & \multirow[b]{2}{*}{$\cdots$} & High & 5,988 & 15,107 \\
\hline & & & Low & 2,320 & 5,53 \\
\hline
\end{tabular}

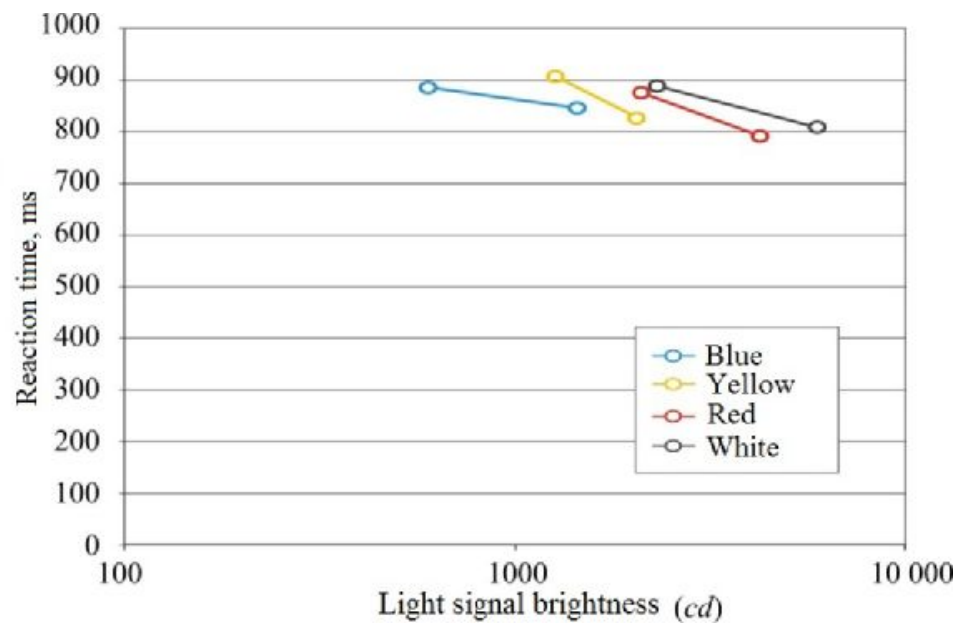

Figure 3. Time of reaction to light signal

Minimal reaction time is registered in case of red light with wave length equal to 636 nanometers (Figure 3) [8].

Modern red LEDs with predominant wave length within radiation spectrum 625-630 nanometers have light flux which is 2-3- times more intense than in LEDs with wave length equal to 640-645 nanometers but their coloration coordinates are not within the existing standardized coloration range (Figure 4) [4]. Manufactures of red LEDs together with experts from the photometric laboratory of the labor protection department at All-Russian Research Institute of Railway Hygiene thought it necessary to examine possibilities how to extend boundaries of red signals coloration area for railway traffic lights. The examination was to be in a form of an experiment during which probability of perceiving a red signal with coloration coordinates corresponding to red LEDs with predominant wave length equal to 625630 nanometers was assessed under real life conditions of traffic lights operation.
In the course of the experiment responses given by an observer concerning a signal color were put into the $\log$ in column, where figure "1" meant yellow color, and figure "2" meant red color [4]. Time of color sense in seconds was fixed in another column. The consequence of the given series of signals was put into the third column where figure "1" meant yellow color with coloration coordinates $x_{1}=0.612, y_{1}$ $=0.385$; figure " 2 " meant red light with coordinates $x_{2}=0.703, y_{2}=0.297$; figure " 3 " meant red light with coordinates $x_{3}=0.713, y_{3}$ $=0.287$ (table 4).

If we analyze the given data we can see that if a red light wave length is close to 650 nanometers than probability of correct color sense increases and response time to red light goes down. It is important when we determine a stopping distance length for a vehicle under various weather conditions. Light and color thresholds are determined in light technique for a small-sized light source (figure 5). 


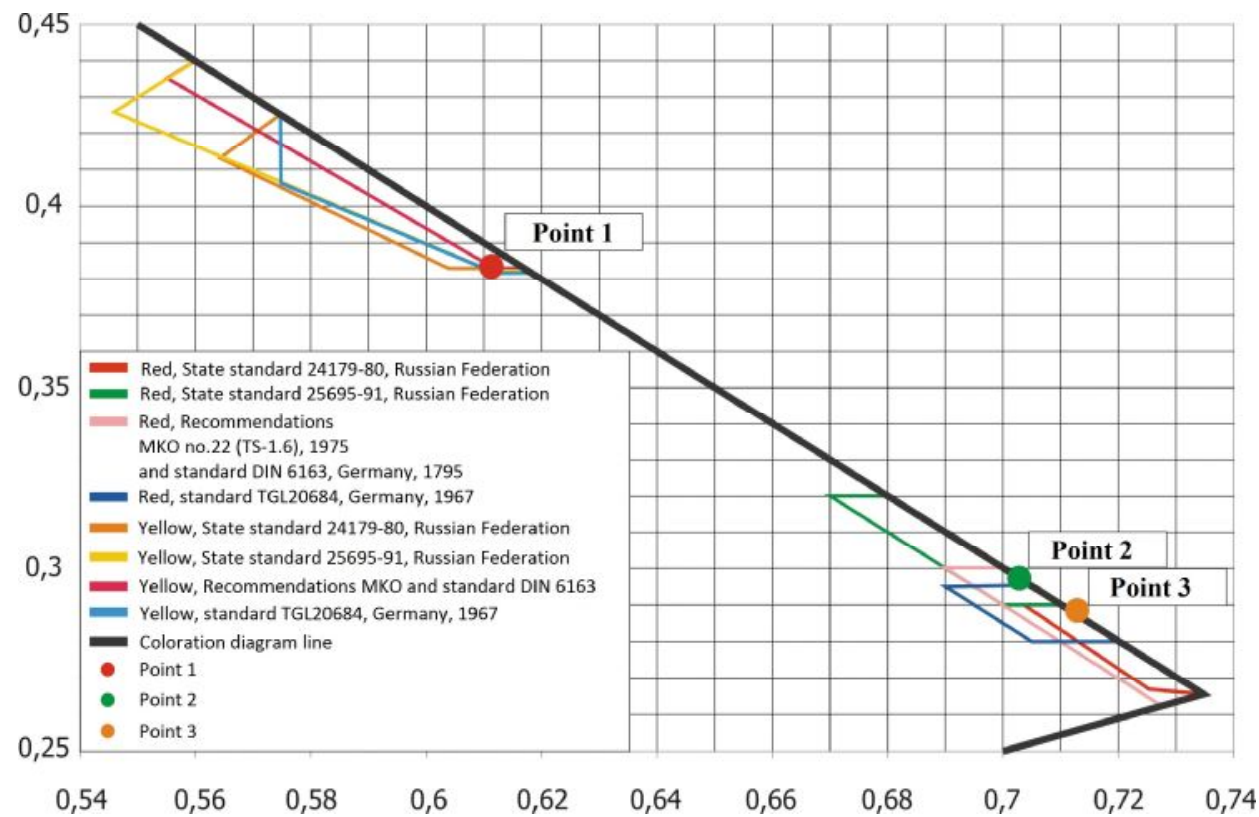

Figure 4. Coloration coordinates with signal color areas as per standards accepted in various countries

Table 4

Experimental results on light signals determination

\begin{tabular}{|l|c|c|c|c|c|c|}
\hline \multicolumn{1}{|c|}{ Background; brightness, cd/m2 } & \multicolumn{3}{c|}{ Sky, $5060 \div 17700$} & \multicolumn{3}{c|}{ Green, $107 \div 640$} \\
\hline \multicolumn{1}{|c|}{ Number of examined coloration point } & $\ll 1 »$ & $\ll 2 »$ & $\ll 3 »$ & $\ll 1 »$ & $\ll 2 »$ & $\ll 3 »$ \\
\hline Number of presentations $(n)$, quantity & 867 & 866 & 867 & 205 & 208 & 207 \\
\hline Number of mistakes in color determination, quantity & 3 & $\mathbf{3}$ & 2 & 0 & 0 & 0 \\
\hline Probability of correct color determination $(P)$ & 0,9965 & 0,9966 & 0,9977 & 1,0 & 1,0 & 1,0 \\
\hline Average determination time $\left(\tau_{\mathrm{cp}}\right), \mathrm{s}$ & 1,030 & 1,005 & 0,996 & 0,814 & 0,731 & 0,715 \\
\hline Quadratic mean error assessment $(s), \mathrm{s}$ & 0,237 & 0,251 & 0,242 & 0,199 & 0,167 & 0,124 \\
\hline
\end{tabular}

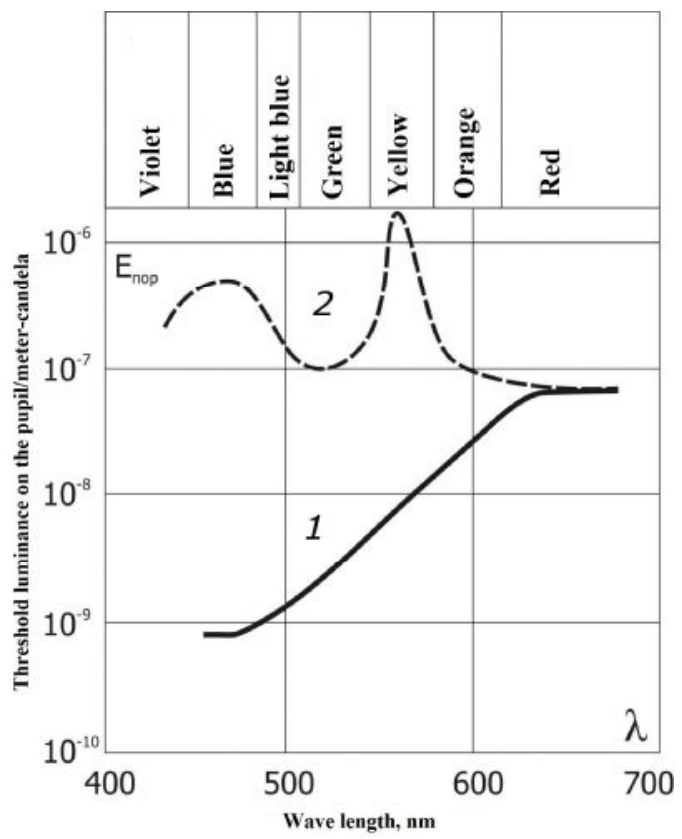

Figure 5. Light (1) and color (2) threshold for a small-sized light source 
We can see from the data on light and color threshold ratio that a man simultaneously sees light and determines its color starting from wave length equal to 650 and under certain luminance. It is hard to explain this fact on the basis of planar Jung-Helmholtz hypothesis [6], but it is clearly explained if we apply fiber-optical approach to "Mueller cell cone" system functioning.

In 2007 researchers led by Kristian Franze, a scientist employed at Cambridge University, revealed that one type of retina glia well-known as Mueller cells functioned as optical fibers when directing light to photoreceptors. But still there was no answer to a question: how come that those natural optical fibers supported two types of photoreceptors: rods which operated under weak lighting, and cones which helped people to see in bright daylight.

Those cells were first described by Heinrich Mueller, a German anatomist (18201864). They have a peculiarity, namely, they are located from the inner limiting membrane (which is adjacent to the vitreous humor) up to the outer limiting membrane. Cells bodies are located in the inner granular layer. Mueller cells architectonic loss matters a lot when retina layer separation occurs. Results of research accomplished in Leipzig University in 2007 showed that Mueller cells had optical function. They collect light from the retina anterior surface and conduct it to photoreceptors located on its posterior surface just like a fiber-optical cable. if not for Mueller cells, light would get to photoreceptors being diffused and it could result in lower visual acuity. Researchers both from Leipzig and Gottingen Universities in Germany and Universidade Central De Caribe Bayamon, Puerto-Rico, and Cambridge University in Great Britain detected how light was directed at Mueller cells (Figure 6). Having done that, they corrected a conventional visual analyzer system. Mueller cells operate as optical fibers, they direct and concentrate yellow-green light spectrum which many cones are maximum sensitive to. Blue light leaks from Mueller cells to activate rods.

Yellow spot cuts out waves with length equal to $450-460 \mathrm{~nm}$ from the whole blue spectrum. Mueller cells contain a focon for collect- ing and receiving diffused light from a point in space changing light refraction index as per their length (Figure 7).

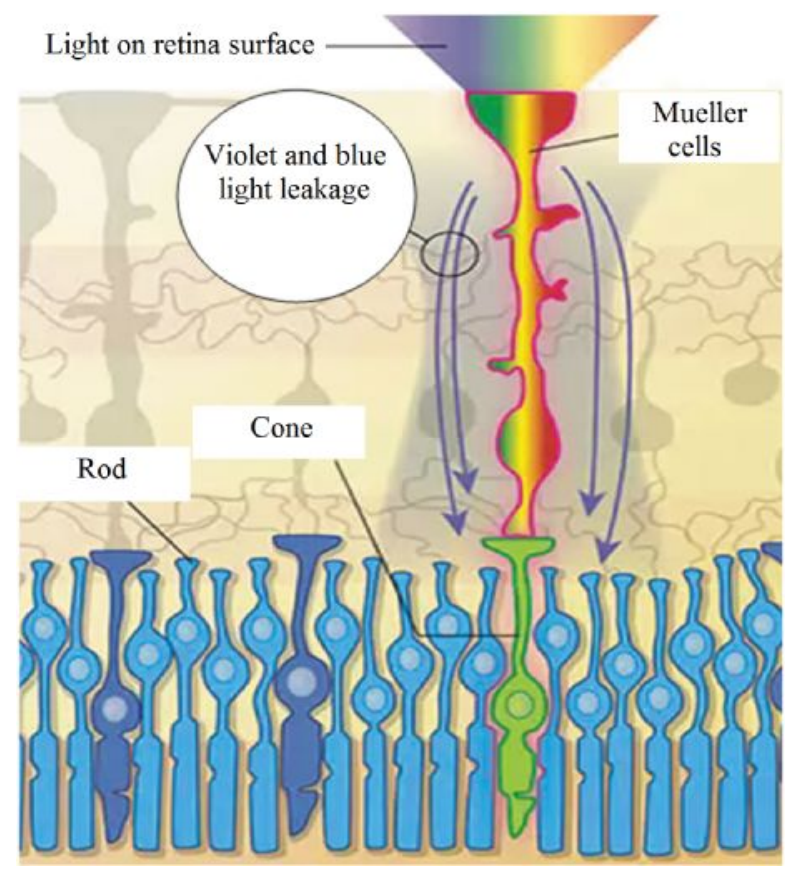

Figure 6. Optical Mueller cells and leakage of violet and blue light

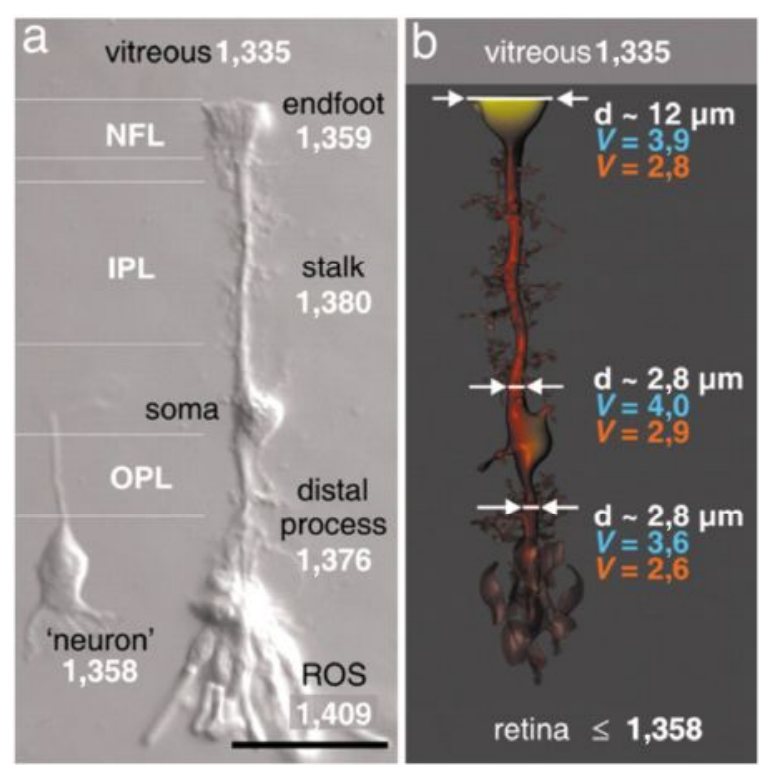

Figure 7. General outlook of Mueller cell and distribution of refraction index values as per its length [12]

Scientists from Israel Technological Institute in Haifa detected that Mueller cells operated as optical fiber [13].

Here Mueller cells lit by white light propagate wave lengths in green-red area for two cones types, and blue-violet light gets through 
retina to activate rods. Maximum light concentration in Mueller cells is observed in yellowgreen area of light spectrum at wave length being equal to $560 \mathrm{~nm}$ [13].

University researchers led by Amichai Labin examined increased retina of a cavy applying confocal microscopy and detected that each Mueller cell combined with an individual cone, and almost $90 \%$ of all the cones were linked to those cells. Optical fiber effect could increase a number of photons reaching one cone almost 11 times.

There are a lot of works dedicated to cones and rods but none of them has detailed an optical scheme describing how light gets on photosensitive opsins and how it penetrates into pigment epithelium cells bodies. There are hypotheses on operational principles for rods and cones, and external parts of their membranes which can be considered as physical analogues of a wave guide with a conical and cylinder form in the eye transparent body medium (liquid medium) [10, 11]. It gives an opportunity to review traditional ideas on visual process. According to Medeiros, an external section of a cone membrane can function as a cone wave guide [11]. Wide cone section meets entering rays which are perceived by the membrane acting as a cone wave guide in the liquid medium of the eye transparent body (the eye liquid medium). The order of rays focusing in this medium is opposite to the order of rays focusing in the air optical system (they focus as per chromatic aberration depending on a wave length). Their focusing before entering the membrane and entering it are opposite and it is regulated by specific functioning of the membrane cone form; it operates as a cone wave guide in the cone structure where walls have various reflecting capacity and various refraction indices which fixes the order which rays enter in: reds $\rightarrow$ green $\rightarrow$ blue (for color sight trichromatism system), for example, in primates and people (Figure 8).

The work gives the results of modeling light spectrum distribution as per optical cone length and optically transparent cone walls. Mueller cells spectral features correlate well with the eye visibility curve (Figure 9, 10) [11]. Research in this field still continues.

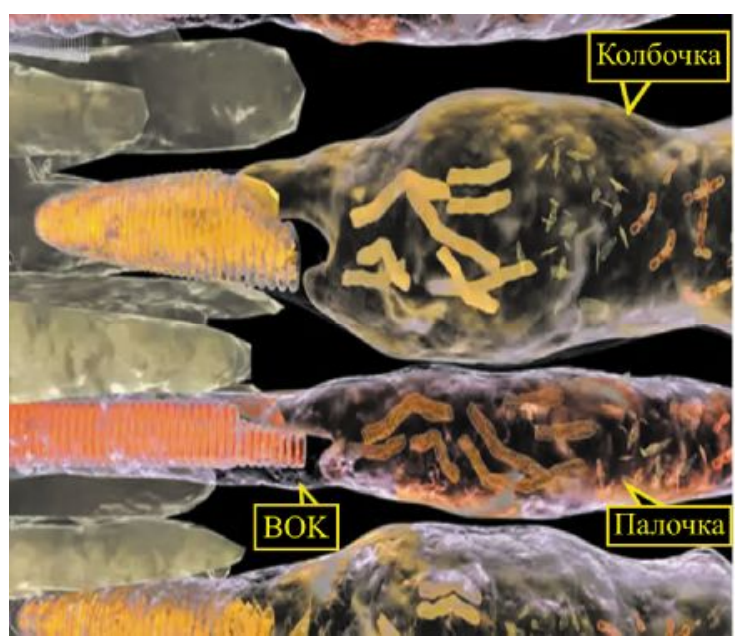

Figure 8. Rods and cones structure with fiber-optical wedge detection (FOW) [7]

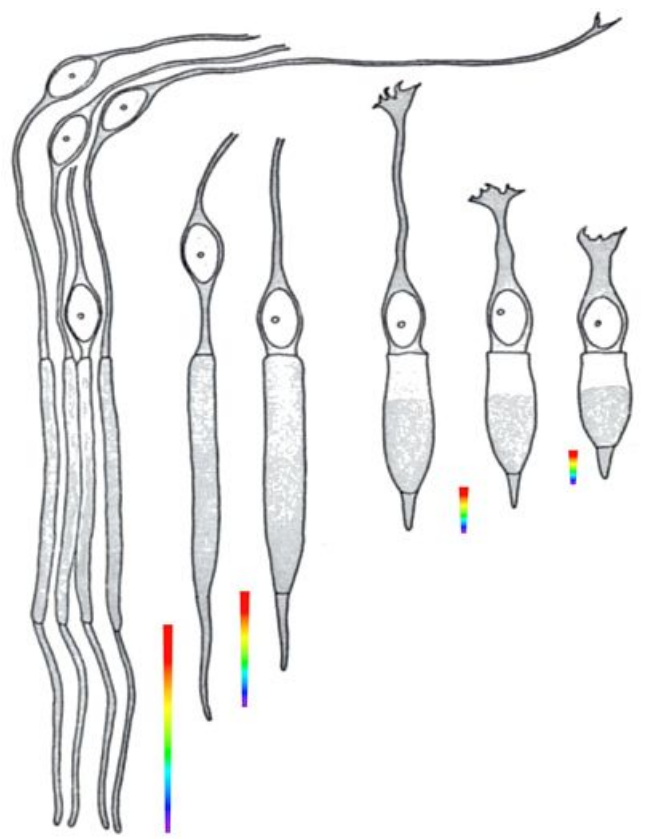

Figure 9. Forms of light spectrum passing through retina

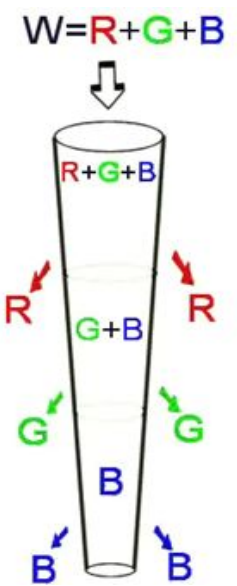

Figure 10. Cone fiber operation as wave guide for light spectrum rays 
This approach clearly shows how light gets into exterior segments of rods and cones and into pigment epithelium cells bodies; the model as well enables assessing color determination for various signals, notably, as per determination delay time.

Assessment of time delays in light perception matters a lot for car drivers and locomotive drivers.

There are experimental results for time delays (in milliseconds) which can be derived for any wave length, $\lambda$ (in millimicrons), concerning perceptual delay of $650 \mathrm{~nm}$ red light, which cam approximately look like:

$$
T_{\text {delay }}(\mathrm{msec})=97.5-0.15 \lambda(\mathrm{nm}) .
$$

It gives zero delay (msec) for $650 \mathrm{~nm}$ red light and it can give up to $30 \mathrm{msec}$ delay for the shortest light wave. The data show that there is time dispersion (delay) between blue and red light. For example, light-blue light $(450 \mathrm{~nm})$ is perceived with an approximately 30 -sec delay in comparison with red light $(650$ $\mathrm{nm})$.

Systematizing the knowledge on color determination as per 3D "Mueller cell - cone" system helps to clarify existing knowledge on planar Jung-Helmholtz 3-color hypothesis concerning spectral decomposition of white light and time delays in perception of red, green, and blue light. It has great applied significance in providing traffic safety and reducing negative influence exerted by the environment on human health.

Relevant administrative actions are taken when drivers pass in spite of red signals; unfortunately, there are no such actions related to providing $100 \%$ red signal determination allowing for the human eye structure.

For example, reasons for passing under red signals on railroads are detailed in "Instruction for a locomotive team concerning prevention of passing traffic lights with inhibiting signals" which was approved on January 11, 2011.
When movement speed increases from 40 $\mathrm{km} / \mathrm{h}$ to $80 \mathrm{~km} / \mathrm{h}$, a driver reaction time almost doubles; we should remember that many of them drive locomotives at a speed equal to 100 $\mathrm{km} / \mathrm{h}$ or faster and are constantly under stress.

At night reaction time almost doubles in comparison with average daily one. Besides, alcohol aftereffects make for its 1.3 times increase; working conditions of a locomotive driver provide for almost the same increase.

Medical observations conducted for more than a hundred years prove that smoking has an adverse effect on eyesight. Effects exerted by toxic substances contained in tobacco smoke often lead to tobacco amblyopia in chain smokers which contributes to weaker perception of red color, lower visual acuity, and spots occurrence in the visual field. All these things are unacceptable for a locomotive driver as per traffic safety provision.

We do not consider mechanism of flash blinding due to changes in Mueller cells optical geometry under excessive dose of light (red and blue) in this paper, though it is wellknown that blinding makes reaction time 2 and even more times longer. The issue will be dealt with later.

\section{Conclusion:}

1. Under LED lighting risks of inadequate color determination are high and it makes negative consequences for vehicles drivers much more probable.

2. Fiber-optical approach to cones functioning clearly explains why red color signal $(650 \mathrm{~nm})$ is determined simultaneously with light sense.

3. Traffic lights for transport systems are to be designed allowing for physiology of light perception by the human visual analyzer. Application of LEDs with wave length shorter than 650 nm should be absolutely excluded.

\section{References}

1. Bakutkin V.V., Kirichuk V.F., Kuznetsova E.V. Vliyanie dinamicheskoi elektroneirostimulyatsii na akkomodatsionnye sposobnosti glaza cheloveka [Influence exerted by dynamic electric neurostimulaiton on accommodation abilities of a human eye]. Problemy opticheskoi fiziki i biofotoniki: materialy XIII Mezhdunar. molodezhnoi nauchnoi shkoly po optike, lazernoi fizike i biofotonike [Issues of optical phys- 
ics and biophotonics: materials of the XIII International youth scientific schools on optics, laser physics and biophotonics]. Saratov, Novyi veter Publ., 2009, 219 p. (in Russian).

2. Berman S.M., Klier R.D. Nedavno otkrytyi fotoretseptor cheloveka i predydushchie issledovaniya $\mathrm{v}$ oblasti zreniya [Recently discovered human photoreceptor and previous research in the sphere of human sight]. Svetotekhnika, 2008, no. 3, pp. 49-53 (in Russian).

3. Deinego V.N., Ivanov V.F. Raduga cvetov izoljacii provodov v svete svetodiodnogo osveshhenija [Rainbow of wire insulation colors under LED lighting]. KABEL-news, 2013, no. 2. Available at: http: //www.ruscable.ru/article/Raduga_cvetov_izolyacii_provodov_v_svete_svetodiodnogo_osveshheniya (18.06.2016) (in Russian).

4. Agafonov D.R., Murashova M.A., Nikiforov S.G., Pinchuk O.P., Stoljarevskaja R.I. Issledovanija vizual'nogo vosprijatija krasnyh zheleznodorozhnyh svetoforov na osnove svetoizluchajushhih diodov [Research on visual perception of red railway traffic lights based on LEDs]. Svetotehnika, 2003. Available at: www.led-e.ru/assets/files/pdf/Svetodiod-svetofor.pdf (22.09.2016) (in Russian).

5. Klinicheskaya anatomiya organa zreniya: chasti tsiliarnogo tela [Clinical anatomy of a sight organ: ciliary body parts]. StudFiles: failovyi arkhiv studentov. Available at: http: //www.studfiles.ru/preview/2243441/page: 7/ (15.10.2016) (in Russian).

6. Teoriya Yung-Gel'mgol'tsa [Jung-Helmholtz theory]. Spravochnik khimika 21: khimiya $i$ khimicheskaya tekhnologiya. Available at: http: //chem21.info/info/279269/ (03.07.2016) (in Russian).

7. $3 \mathrm{~d}$ rods cones eye anatomy with bipolar pigmented amacrine horizontal cells epithelium optic nerve and cell nucleus body human medical. TurboSquid. Available at: http: //www.turbosquid.com/3dmodels/max-rods-cones-eye-anatomy/570819 (08.10.2016)

8. Flannagan M.J., Blower D.F., Devonshire J.M. Effects of Warning Lamp Color and Intensity on Driver Vision: Report of work on Non-Blinding Emergency Vehicle Lighting (NBEVL). Michigan, 2008, 54 p.

9. Franze K., Grosche J., Skatchkov S.N., Schinkinger S., Ch. Foja, D.Schild, O.Uckermann, K.Travis, A.Reichenbach, J.Guck.Müller cells are living optical fibers in the vertebrate retina. PNAS, 2007, vol. 104, no. 20, pp. 8287-8292. DOI: 10.1073/pnas.0611180104.

10. Huth G.C. A Modern Explanation for Light Interaction with the Retina of the Eye Based on Nanostructural Geometry: Rethinking the Vision Process. Available at: http: //www.ghuth.com/ (21.07.2016).

11. Labin A.M., Safuri Sh.K., Ribak E.N., Perlman I. Müller cells separate between wavelengths to improve day vision with minimal effect upon night vision. Nature Communications, 2014, no. 4319. DOI: $10.1038 /$ ncomms5319

12. Luoma Ju., Flannagan M.J., Sivak M., Aoki M., Traube E.C. Effects of turn-signal color on reaction times to brake signals. Michigan, 1995, $19 \mathrm{p}$.

13. Medeiros J.A. The Cone Spectrometer Model (CSM). Color Vision: A New Understanding. Available at: http: //conesandcolor.net/_F_CSM.htm (22.10.2016)

14. Navarro R., Santamaría J., Bescós J. Accommodation-dependent model of the human eye with aspherics. Journal of the Optical Society of America A, 1985, vol. 2, no. 8, pp. 1273-1280. DOI: 10.1364/JOSAA.2.001273.

15. Plainis S., Ginis H.S., Pallikaris A. The effect of ocular aberrations on steady-state errors of accommodative response. J.Vis, 2005, vol. 5, no. 7, pp. 466-477.

16. Tarrant J., Roorda A., Wildsoet C.F. Determining the accommodative response from wavefront aberrations. Journal of Vision, 2010, vol. 10, no 5, pp. 4.

Kaptsov V.A., Deinego V.N. Health risks occurring when color is percepted under led lighting. Health Risk Analysis, 2017, no. 2, pp.16-24. DOI: 10.21668/health.risk/2017.2.02.eng

Received: 10.03 .2017

Accepted: 16.05 .2017

Published: 30.06 .2017 